\title{
DIE OPVOEDINGSTAAK VAN DIE UNIVERSITEIT
}

Die vraag na die opvoedingstaak van die universiteit is onafskeidelik verbonde aan die siening wat gehuldig word aangaande die opvoeding, die student en die universiteit. Dit is derhalwe nodig om vooraf hierdie begrippe in oënskou te neem. Met inagneming van die beskikbare tyd daartoe, sal die drie begrippe slegs kursories en in so 'n mate ontleed word as wat nodig is om die sentrale tema te belig.

\section{Opvoeding}

Die opvoeding het slegs op die mens betrekking. Net die mens kan opvoed en opgevoed word, want net die mens beskik oor die moontlikheid om uit te styg bo die situasie waarin hy verkeer, om dit te evalueer, dit te omvorm en aan sy behoeftes diensbaar te maak; slegs die mens beskik oor die Godgegewe moontlikheid om te kies hoe hy sal antwoord op bevraging en om aktief-kiesende en reagerende in verantwoordelikheid aan God mee te werk aan sy eie wording.

Opvoeding is 'n intieme wisselwerking, 'n geestelike dialoog in 'n ware ontmoetingsituasie, gekenmerk deur openheid, onderlinge vertroue en liefde, tussen 'n gevormde, volwasse opvoeder en 'n hulpbehoewende, volwasse-wordende opvoedeling, waartydens die opvoeder met sy opvoedingsmiddele (leerstof, metode, tug, ens.) doelbewus, opsetlik en planmatig hulp en leiding verleen aan die opvoedeling. Sowel opvoeder as opvoedeling is aktief betrokke by die opvoeding: die opvoeder struktureer die opvoedingsituasie, berei en bemes die akker, kies en bied die voedsel - en veral geestelike voedsel - aan, en gryp in die handelinge, die beantwoording van die opvoedeling, in deur te verbied, te vermaan, te straf, raad te gee en deur as voorganger op te tree. Aldus rig hy die wording van die opvoedeling doelbewus en planmatig. Die opvoedeling antwoord aktief op hierdie opgawe: hy steek sy hande - ook in geestalike sin - uit om die aangebode voedsel te neem, hy assimileer dit denkend, reageer daarop, leer, groei kwantitatief en ontwikkel kwalitatief.

Aangesien opvoeding dan die doelbewuste, planmatige toerusting en leiding van die groei, ontwikkeling, wording, van die volwasse-wordende, of ook onvolwaardige volwassene, in 
' $n$ bepaalde rigting is, is dit noodwendig gerig op die bereiking van 'n vooraf gevisualiseerde beeld van die opgevoede mens. Opvoeding is derhalwe ook vorming of toerekenbare, verantwoordelike totstandbringing.

Omdat opvoeding dan 'n doelbewuste ingrype en meewerke, totstandbringing is, kan dit nooit beskou word as 'n natuurlike neweproduk, 'n uitvloeisel van wetenskapsbeoefening nie. Dit kan nie aanvaar word dat opvoeding noodwendig uit kennisbemagtiging, navorsing en metodebeoefening aan 'n universiteit sal vloei nie. Die dosent moet in hierdie werksaamhede opvoed en geskikte geleenthede skep vir die groei en ontwikkeling van die student.

Soos uit die voorgaande blyk is die opvoeding noodwendig normatief, want dit word gedra en bepaal deur die lewens- en wêreldbeskouing, die waardes, norme en doeleindes van die opvoeder; dit betrek die hele opvoedeling - fisies en psigies as totaliteit in die opvoedingsituasie; en dit is gerig op die toerusting, vorming en leiding van natuurlike groei en ontwikkeling van die aktief aan die opvoeding deelnemende volwasse-wordende, sodat hy as selfbewuste, selfstandige, adekwaat toegeruste, ewewigtige mens sy plek tussen mense kan vind in ' $n$ lewe van diens aan God en die medemens.

Die opvoeder wat sy opvoeding grondves op die Woord wat ewig waar is, sal noodwendig 'n eiesoortige mens wil vorm, 'n mens wat God vrees en eer, wat dors na die kennis van God en wat biddend die geloof deur Christus begeer - maar tegelykertyd ook mens tussen mense op aarde en wat, sover as wat menslik moontlik is, toegerus is vir alle goeie werke. Sodanige opvoeding omvat noodwendig ewewigtige en geintegreerde biologiese, fisiologiese, psigologiese, logiese, sosiologiese, politiese, estetiese, etiese, filosofiese en religieuse toerusting, vorming en ontwikkeling van die opvoedeling. ${ }^{1}$

\section{Die student}

Die opvoeding hang grootliks af van hoe die opvoeder die opvoedeling en die lewe sien. Daarom is dit nodig om die opvoedeling aan die universiteit - die student - van nader te beskou.

Vir die Christen vind die lewe, die mens en ook die opvoeding hulle oorsprong in God, die Skepper van hemel en 
aarde. Mens en lewe vind ook hulle wese en aard in God: die lewe is na sy aard in die skepping van plant, dier en mens deur die Here daarin gelê; en die mens is na die beeld en gelykenis van sy Skepper gemaak met die opdrag om die aarde te bewaak, te bewerk en te beheer. $\mathrm{Na}$ sy wese is die mens die beeld en gelykenis van sy Skepper, geskape in alle waarheid, geregtigheid, heiligheid, goedheid en skoonheid. Na sy wese en aard is die mens anders as selfs die mees hoogstaande dier: hy groei en ontwikkel anders en hy het ' $n$ ander bestemming, nl. die ewige geluksaligheid. Die mens het deur sy ongehoorsaamheid in die sonde en verdoemenis geval, maar deur die genade van God en die soenverdienste van Christus kan hy daaruit verlos word.

Hierdie basiese siening van die mens bepaal vir die gelowige Christen die weg en die einde van die opvoeding. Die opvoeding is noodsaaklik om die gevalle mens in die vrese van God groot te maak en om hom te lei tot die kennis van en die liefde vir God en tot die soeke van die geloof in God. Die opvoeding is ook moontlik omdat God die nodige gawes van hoof, hart en hand in die mens gelê het.

Teen hierdie agtergrond moet die student van nader beskou word.

Dit word allerweë aanvaar dat die huidige stand van kennis aangaande die student in sy snel bewegende twintigste eeuse lewensituasie - en veral van die student in die opvoedingsituasie - veel te wense oorlaat en dat navorsing op hierdie terreine dringend nodig is. Dit is by die beskouing van die student ook nodig om die heterogeniteit van die studentekorps in gedagte te hou: daar is voorgraadse studente wat wissel van eerste- tot derdejaars en daar is nagraadse studente; binne iedere groep is daar groot onderlinge verskille t.o.v. bykans iedere denkbare aspek van menswees - chronologiese ouderdom, kennis, rypheid, intelligensie, aanleg, vermoë, persoonlikheid, motivering, belangstelling ens. Daar is dus nie so iets as 'n gemiddelde of tipiese student nie. Studente is indiwidue, elk met sy eie kenmerke wat die gesamentlike resultaat is van oorerwing en omgewing. Ten slotte moet in gedagte gehou word dat die groei, ontwikkeling en rypwording van die mens 'n kontinue gebeure, onderworpe aan die invloed van onderling verskillende en soms snelwisselende faktore is. Die studentejare moet derhalwe gesien word as deel van die aaneenlopende 
opweg-wees na volwassenheid.

Met inagneming van die voorgaande voorbehoude bestaan daar egter nogtans 'n redelike konsensus van opinie aangaande sekere algemeen voorkomende eienskappe van studente, en kan daar gepoog word om hierdie eienskappe saam te vat.

Die oorgrote meerderheid studente is jongmense tussen die ouderdomme van 18 en 23 jaar, d.w.s. laat-adolessente. Hulle is reeds gedurende die 12 jaar van skoolonderwys deeglik geselekteer, en die meerderheid val intellektueel onder die boonste kwartiel van die bevolking met 'n I.K. van bo 110 . Benewens 'n goeie verstandelike vermoë is hulle in die algemeen bo die gemiddeld begaafd met ' $n$ goed ontwikkelde wil, deursettingsvermoë en roepingsbewustheid. Die student is derhalwe lid van 'n eksklusiewe groep wat in vele opsigte van die ,gemiddelde" laat-adolessent verskil.

Die verstandelike groei is in die reël teen 18-jarige leeftyd bykans voltrek, sodat die student denkende mens is wat veral soek na die essensie, die diepere sin van mens, lewe en skepping en na die samehang van kennis. Vanweë sy verstandelike rypheid en toebedeeldheid is hy skerpsinnig en krities, wil hy self dink en sy eie opinie oor sake vorm, maar hierin is hy nog relatief onervare.

Ook sy wils- en emosionele lewe het reeds 'n gevorderde graad van groei, ontwikkeling en stabiliteit bereik; sy belangstelling is gerig op die sosiale, op aanname deur en verkeer met sy gelykes, op groepaktiwiteite en -sport, op voorbereiding vir 'n beroep, op kuns, letterkunde en wetenskap in die algemeen maar op ' $n$ lieflingswetenskap in die besonder, op politiek, en op die soek na 'n lewensmaat.

Al beskik hy oor al die eienskappe - na liggaam, verstand, gevoel en wil - van die grootmens; al het hy sy ek ontdek en sy eie leemtes en voortreflikhede leer ken en aanvaar; al wil en kan hy vir homself besluit en die lewe aandurf; al is hy in sommige opsigte reeds die volwassene se gelyke, verskil hy nogtans gradueel en in sommige opsigte ingrypend van die volwalssene: die volslae integrasie van die persoonlikheid wat ewewig, selfbeheersing, bestendigheid en sekerheid bring is nog nie voltrek nie; die hantering van die self en wisselwerking met andere binne die ingewikkelde lewensituasie verg nog ervaring en oefening; die student se voorbereiding vir die beroepslewe, sy kennisbemagtiging, metodebeoefening en gesindheidsverwer- 
wing is nog nie voltooi nie (daarom is hy immers student!); hy is nog nie onafhanklik nie want sy ouers, of ander instansies (beursgewers) moet hom onderhou; hy is nog soeker na 'n vaste, wetenskaplik gefundeerde lewens- en wêreldbeskouing, ensovoorts.

Die student verkeer derhalwe „... op die grens van die nie-meer-kind-te-wees en die nog-nie-volwasse-te-wees". ${ }^{2} \mathrm{Hy}$ is nog volwasse wordende of minstens onvolwaardige volwassene wat opvoeding - soos hierbo omskryf - behoef.

Hierdie nog-vis-nog-vleeswees skep die verskillende konfliksituasies wat De Klerk so raak saamvat: ${ }^{3}, \ldots$ konflik tussen die vryheidsverwerwing van die stadium en die vryheidsbeperkinge wat nog opgelê word; konflik tussen die prikkeling van verskillende behoeftes soos seksuele behoeftes en ekonomiese onafhanklikheidsbehoeftes en die beperkings ten opsigte van die bevrediging daarvan. Hierdie verskillende konflikte veroorsaak emosionele onewewigtigheid wat geuit word in, onder andere, 'n absolutisme, 'n antagonisme, 'n drang na selfstandigheid wat geuit word in aggressie, 'n verstewiging van die ek ten koste van ander, ' $n$ beterweterige gewigtigheid en 'n baldadige speelsheid wat dikwels die neiging tot ontaarding vertoon; verder onsekerheids- en skuldgevoelens". Die student is bewus van sy eie onervarenheid en onvolkomenheid en vertoon onder 'n kors van bravade 'n afhanklikheid en behoefte aan simpatieke, dog goed gemotiveerde en ferme, leiding deur 'n ervare, gerespekteerde volwassene, wat ook 'n veilige hawe is waarheen in uiterste nood gevlug kan word. Maar, die student maak ook aanspraak op toenemende vryheid, ooreenkomstig sy graad van rypheid, om te kan kom tot selfdissipline, en op geleenthede om volwasse gedrag te oefen.

Dit is uit die voorgaande duidelik dat die student as volwasse-wordende, of as minstens op sommige terreine onvolwaardige volwassene, nog steeds in die volledige sin van die woord opgevoed moet word. Dit is ook duidelik dat die tersiere opvoeding en die voorafgaande skoolopvoeding op 'n natuurlike wyse bymekaar moet aansluit; dat die aard en behoeftes van die student daarop dui dat die opvoeding van die mens in sy totaliteit moet voortduur, maar dat daar 'n ingrypende klemverskuiwing moet plaasvind wat die hele tersiêre opvoeding na doel, inhoud en metode raak: om die student se toerusting, vordering en ontwikkeling volkome te maak, moet die klem ge- 
plaas word op wetenskapsbeoefening - in sy breedste sin en op voorbereiding vir toetrede tot 'n beroep. Dit spreek vanself dat ook dit aan hierdie Universiteit na Christelike model sal geskied. Dit stel - met inagneming van die aard van die student - besondere eise aan die tersiêre didaktiek, en veral aan die dosent...

\section{Die universiteit}

Van die vrye Middeleeuse universitas magistrorum et scholarium en studium generale, die middelpunt van kennis en onderrig van hulle tyd, is 'n lang pad afgelê om tot by die moderne universiteit te kom, en langs hierdie pad het die universiteit baie verander. Vroeër was die meesters die alleenbesitters van kennis, omdat daar nie boeke was nie en die studium generale was bewaarder en oordraer van kennis en wel van die sewe vrye kunste, die medisyne, regte en teologie alles wat bekend was en wat bygedra het tot die hoogste toerusting van die mens van die tyd. Veral gedurende die agtiende en negentiende eeue is die Europese universiteit toenemend onderwerp aan die staat, diensbaar gemaak aan die nasionale behoefte en aspirasies en het hy toenemende - moontlik selfs oordrewe - klem op navorsing geplaas met spesialisasie as noodwendige uitvloeisel. In hierdie proses is die vroeëre opvoedingsfunksie toenemend verwaarloos - die Engelse Oxford en Cambridge was egter konserwatiewe uitsonderings wat traag gevolg het. Met die ontploffing van studente-inskrywings is die skaal tans besig om terug te swaai: die besef groei dat navorsing, beroepsvoorbereiding en spesialisasie nie tot nadeel van onderwys en opvoeding van die hele mens mag strek nie, dat goeie leermeesters ewe noodsaaklik is as goeie navorsers en dat spesialisasie sonder geheelvisie innerlike verskeurdheid in die hand werk. Vandaar die wêreldwye besinning oor breë integrerende kursusse, oor die funksies van universiteite, oor tersiêre didaktiek en selfs oor die toerusting van tersiêre opvoeders. ${ }^{4}$ Die moderne universiteit is 'n universiteit soekende na klaarheid oor homself, en in hierdie soeke kan ons Universiteit moontlik ' $n$ belangrike bydrae lewer.

By verskillende geleenthede is die wese en funksies van die universiteit deur lede van hierdie Universiteit onder die loep geneem, ${ }^{5}$ ten einde die denke oor die universiteit te orden. 
Vir die doeleindes van hierdie lesing bepaal ons die aandag slegs by die funksies van die universiteit in soverre dit sy opvoedingstaak belig.

Die universiteit is 'n plek waar mense wetenskap beoefen, 'n middelpunt van geleerdheid, onderrig en opvoeding. Dit is die derde en hoogste trap van die kontinue onderwysstelsel van 'n land. Waar die primêre onderwys in die verpligte volkskool gerig is op die elementêre, hoofsaaklik empiriese, feitelike inhoud en op bemagtiging van basiese vaardighede; die sekondêre skool, tans ook grootliks onderhewig aan skoolplig, gerig is op algemene opvoeding, op die bybring van kennis sonder om spesifieke aandag aan die beheersende struktuur daarvan te gee, en op aanpassing van die inhoud by die kind; daar is die universiteit, anders as die skool, nie verplig, bedoel vir die begaafdes wat kan aanpas by die vereiste kennispeil. Die tersiêre onderwys is suiwer wetenskaplik en professioneel gerig. Dit bring opvoeding van die hele mens, w.o. uitbreiding van kennis deur leer, maar ook kennisontginning (navorsing) en die verwerf van insig in die grondliggende struktuur en samehang van kennis. Dit is, anders as die skool, kreatief en filosofies.

Die drie vlakke van opvoeding behoort op mekaar voort te bou, en op 'n natuurlike wyse by mekaar aan te sluit.

Volgens 'n Memorandum oor die universiteitswese in die Republiek van Suid-Afrika, voorgelê aan die Staatspresidentskommissie van ondersoek na hierdie vraagstuk deur die Potchefstroomse Universiteit vir C.H.O. wat in 1969 saamgestel is, kan die funksies van die universiteit soos volg saamgevat word: "... beoefening van die wetenskap in al sy vertakkinge, navorsing, opvoeding van mense toegerus om die een of ander professie te beoefen, om die staatkunde, kultuur en kuns te beoefen en te waardeer. Hierdie funksies geld vir alle universiteite, maar die P.U. vir C.H.O. is 'n besondere universiteit, wat gefundeer is op Christelike beginsel, en daarom het hy ook besondere funksies. Hierdie Universiteit moet - soos ander universiteite - vir sover dit menslik moontlik is elke vertakking van die wetenskap beoefen, navors en opvoed. Maar, die beginsel van hierdie Universiteit verg veel meer, nl. 'n wetenskapsbeoefening en opvoeding soos belig deur die Skrif. Daarom het die P.U. vir C.H.O. ook sy opvoedingsfunksie op 'n besondere wyse geformuleer, nl. as „Intellektuele ontwikkeling en vorming en professionele toerusting... en opvoeding van die 
hele mens tot mens van God wat in staat sal wees om elke lewensituasie in die lig van die Woord te beheers". 6

\section{Die opvoedingstaak van die universiteit}

Gesien uit die beskouing van die opvoeding, die student en die universiteit het die universiteit 'n besondere en 'n algemene taak t.o.v. die opvoeding, maar hierdie take is onderling verweef. Die besondere taak, eie slegs aan die universiteit, is die intellektuele en professionele toerusting, ontwikkeling en vorming van die student. Die algemene taak is die voortgesette opvoeding van die student as totale mens. Daar sal vervolgens nader gepresiseer word wat hierdie take behels, en ten slotte sal getrag word om enkele eise aan te dui wat hierdie opvoedingstake aan die universiteit stel.

\section{(a) Nadere omskrywing van die opvoedingstaak}

(i) Intellektuele en professionele toerusting, ontwikkeling en vorming.

Die mens moet hom as lewende wese handhaaf in die fisiese en biologiese omgewing waarin hy deur God geplaas is met die opdrag om die aarde te onderwerp, te bewerk en daaroor te heers. Hiertoe is nodig kennis, die hoogs moontlike ontwikkeling van die denke en toerusting vir 'n beroep.

Dit gaan hier nie oor kennis om die kennis nie, maar oor die bemagtiging van kennis ter wille van roepingsvervulling, oor die verwerf van metodes ter selfstandige verwerwing van kennis, en oor kennis van die kennis. Die student moet die skepping leer ken om dit te kan onderwerp, bewerk en beheers, en hy moet kennis bemagtig om die struktuur van kennis en die plek en beperking van sy wetenskap in die universitas scientarium te begryp. Hiermee word onmiddellik die tweede aspek, nl. ontwikkeling van die denke, betree want begrip van die dieper sin, betekenis en samehang van wetenskap verg 'n wetenskaplike denkwyse en hoogsontwikkelde denke.

Dit is derhalwe $66 \mathrm{k}$ die taak van die universiteit om voldoende en gunstige geleenthede en omstandighede vir die ontwikkeling van die denke en van 'n wetenskaplike gesindheid te skep, om die student bepland en doelgerig voor prikkelende probleemsituasies te plaas, en om hom ook, in ooreenstemming 
met sy graad van rypheid, in die logiese en wetenskaplike benadering daarvan te lei. Sodoende word die student opgevoed tot aktiewe, denkende bemagtiging van kennis, insig, tegnieke en metodes, maar ook tot voortgesette verstandelike ontwikkeling deur eie inspanning. Bingle $^{7}$ beklemtoon tereg die feit dat die universitêre opvoeding deur die toenemende problematiek van die snel bewegende moderne lewe daartoe gedwing word om die klem te verskuif van die oordrag van kennis en metodes - wat vandag van waarde dog móre verouderd is - na toerusting van die student om self metodemaker te word, want langs hierdie weg kan hy daartoe bydra dat die wetenskap nog uitnemender beoefen word en die menslike roeping in die natuur uitnemender vervul word.

Hiermee staan ons reeds midde in die derde aspek van die geïntegreerde besondere opvoedingstaak, want die fondament van professionele voorbereiding is selfstandige, kreatiewe denke en die bestudering van dié vertakking van die ensiklopedie van die wetenskap wat die grondslag van 'n bepaalde professie vorm. Uit die wetenskaplikheid en die vakwetenskap word die mens van die professie gevorm, want wat die beroepsmens van die universiteit meeneem is nie slegs tegniese kennis nie maar ook, en veral, dit wat sy gebruik van tegniese kennis rig. Daarom moet die universiteit nie beroepsopleiding, beroepsafrigting gee nie, dog beroepsvoorbereiding en roepingsleer, ${ }^{8}$ want die universiteit is nie 'n beroepsinstituut nie, wetenskap is nie altyd sinoniem met beroepskennis nie en die akademikus is nie 'n tegniese vakman nie.'

\section{(ii) Algemene opvoeding}

Die universiteit moet hier, uit sy besondere lewens- en wêreldbeskoulike begronding voortbou op die werk van die skool, dog wel op 'n vlak en op 'n wyse wat pas by die peil van ontwikkeling en die rypheid van die student. Dit behels die ewewigtige vorming en ontwikkeling van die student in sy totaliteit - na liggaam, verstand, gevoel en wil - tot kultuurmens. Vir hierdie Universiteit beteken dit die vorming en ontwikkeling van mense van God volkome toegerus vir alle goeie werke en wat in staat sal wees om elke lewensituasie in die lig van die Woord te beheers.

Hiertoe is nodig dat die student gebring moet word tot 
kennis en vrees van God en tot bewuste nalewing van die eerste tafel van die Wet, opdat hy uit liefde tot God sy lewe aan die eer van God sal toewy; dat die student lewensbeskoulik gevorm moet word - en wat hierdie Universiteit betref, Calvinisties lewensbeskoulik; dat die sedelike lewe van die student tot volle ontplooiing gebring moet word en hy gemotiveer word tot bewuste nalewing van die voorskrifte van die Woord in sowel die akademiese as die professionele en persoonlike sfeer; dat die student gebring word tot ontdekking en innerlike belewing van die skoonheid van die skepping en tot insig in die majesteitlike van die Skepper van die skoonheid en die Gewer van die menslike gawes om skoonheid voort te bring en te waardeer; dat die student gebring word tot optimale, gebalanseerde ontplooiing van sy verstand, gevoel en wil; dat die student gebring word tot inpassing in sy sosiale milieu sonder prysgawe van sy beginsels; en ten slotte verg algemene opvoeding dat die student gebring moet word tot inpassing in die nasionale lewe, tot erkenning van die oorkoepeling van die nasionale lewe deur die Goddelike verordeninge, tot erkenning van die beskikking van God oor die wel en wee van volkere en nasies, en tot handhawing en nalewing van die Christelike norme ook in staatkundige en internasionale verband.

Dit is duidelik dat die hele universiteit as totaliteit moet meedoen aan algemene opvoeding; dat die universiteit uit Christelike beginsel die koers van ontwikkeling van die student moet stuur; dat weinig dosente t.o.v. al bogemelde oogmerke 'n groot aandeel sal hê dog dat elke dosent in sy wetenskapsbeoefening, doseerwerk of omgang met die studente voldoende geleentheid sal kan vind om een of meer van bg. fasette te bevorder; en dit is ten slotte duidelik dat 'n ewewigtige bevordering van al die opvoedingsoogmerke eenheid van sin, onderlinge oorleg, gekoördineerde pogings en spanwerk van al die dosente verg.

Al die akademiese magte moet so op die student inwerk dat hy voorberei word vir die lewe, want dan word ook die intellektuele en professionele toerusting, ontwikkeling en vorming geintegreer met die algemene vorming wat uitloop op die mens van God vir alle goeie werke volkome toeberei.

(b) Eise wat die opvoedingstaak aan die universiteit stel Die algemene opvoedingstaak stel die volgende eise aan 
die Universiteit.

1) Dat sy dosente kultuurmense en wetenskaplikes in die rykste sin van die woorde moet wees, maar veral dat hulle lewensbeskoulik gevormd moet wees, sodat hulle doelbewuste en onderling gekoördineerde leiding kan gee deur voorbeeld en woord.

2) Dat sy dosente didakties onderlegd moet wees ten einde hulle in staat te stel om, in soverre hulle vakgebiede en omstandighede hulle daartoe leen, 'n geskikte opvoedingsituasie te skep waarin die hoogs moontlike graad van toerusting, ontwikkeling en vorming van elke student kan plaasvind.

3) Dat die Universiteit voorsiening moet maak vir voldoende geriewe en personeel vir fisiese en psigiese versorging in die koshuise, vir sport, ontspanning, kulturele en sosiale bedrywighede van studente; vir voldoende personeel om werklike ontmoeting tussen dosent en student moontlik te mak; vir 'n wye seleksie uit die ensiklopedie van die wetenskap; vir voldoende fasiliteite vir daadwerklike wetenskapsbeoefening. Hierdeur kan die gunstige groeibodem geskep word vir ontwikkeling.

4) Dat elke dosent deeglik onderlê moet wees in die beginsels van die Christelike wetenskap en opvoeding, want die wyse waarop die inhoud verwerk en aangebied word en die lewensbeskouing wat dit dra en daaruit straal is van kardinale belang. Hiertoe sal 'n mate van opleiding moontlik goed te pas kom en het die departement Interfakultêre Wysbegeerte 'n besondere funksie te vervul.

Intellektuele en professionele toerusting, ontwikkeling en vorming verg die volgende van die Universiteit:

1) Sy dosente moet vakkundiges wees met diepgaande kennis van die wetenskap en wat wetenskap onder die tug van die Woord kan beoefen; hulle moet didakties onderlê wees sodat hulle die vakinhoud sodanig kan aanbied dat insig in die wetenskap geredelik verwerf kan word, sodat hulle die denke effektieŕ kan ontwikkel, sodat hulle die wetenskaplike metode, denke en gesindheid sowel as kreatiwiteit by studente kan ontwikkel, en sodat hulle die inhoud sodanig kan kies en orden dat die essensie nie vervaag in 'n oorladende kennismassa nie en dat die beroep as roeping gesien en aanvaar kan word.

2) Die Universiteit moet enersyds soveel as moontlik ver- 
takkinge van die wetenskap aanbied, maar moet andersyds waak teen oordrewe spesialisasie - veral met die oog op beroepsvoorbereiding - wat die totaalbeeld van die wetenskap kan versnipper. In hierdie opsig het die departement Interfakultêre Wysbegeerte ' $n$ besondere, integrerende roeping, maar die Universiteit moet ook weë en middele (w.o. hierdie interfakultêre lesings) vind om ware akademiese interdepartementele verkeer - wat veel meer is as sosiale verkeer - te bevorder.

3) Die Universiteit moet waak teen utilitaristiese beroepsafrigting i.p.v. wetenskaplik gefundeerde beroepsvoorbereiding enersyds, maar ook andersyds teen verwaarlosing van professionele vorming.

4) Die Universiteit moet toesien dat onderrig steeds genaelstring bly aan navorsing maar ook dat navorsing nie al die ander funksies uitkanker nie.

5) Vanweë die toenemende aantal studente met beroepsopleidings-, aanpassings- en persoonlikheidsprobleme en die velerlei didaktiese probleme in die veeleisende en bewegende moderne universiteitslewe moet die Instituut vir Sielkundige en Opvoedkundige Dienste en Navorsing sterk uitgebou word.

Dept. Tersiêre Onderwys en Voorligting,

S. J. Preller. P.U. vir C.H.O.

1 Vir besonderhede hieroor kyk Coetzee, J. C.: Inleiding tot die algemene opvoedkunde, hfst. XVI.

2 De Klerk, W. J.: Studentevorming. Koers, XXXIV (6), Junie 1967, p. 81.

3 Loc. cit.

4 Clapp, M.: The modern university. Carnell University, 1968.

5 Vgl. uitsprake van Stoker, Taljaard, Coetzee, Bingle en die Sentrale Opnamekomitee van 1965 e.a. skrywers van artikels in Koers.

6 Verslag oor Akademiese en ander aangeleenthede aan die P.U. vir C.H.O., 1966.

7 Rapport aan die Raad van die P.U. vir C.H.O. oor universiteitsontwikkeling, p. 25-26.

8 Vgl. die taak van die departement Interfakultere Wysbegeerte, soos in sy intreerede uiteengesit deur De Klerk.

9 Du Plessis, P. G. W.: Die struktuur van die universiteit. Koers, XXXVI (6), Junie 1969, p. 452. 